\title{
Pesan Dakwah Pada Media Sosial
}

\author{
Tika Kania Nurazizah ${ }^{2 *}$, Saeful Anwar ${ }^{2}$, Bahrudin $^{1}$ \\ ${ }^{1}$ Jurusan Komunikasi Penyiaran Islam, Fakultas Dakwah dan Komunikasi, UIN Sunan Gunung \\ Djati, Bandung \\ 2Jurusan Pengembangan Masyarakat Islam, Fakultas Dakwah dan Komunikasi, UIN Sunan \\ Gunung Djati, Bandung \\ *Email: tika.kania04@gmail.com
}

\begin{abstract}
ABSTRAK
Grup Line Takeru mengemas pesan suara berisikan pesan dakwah yang berkaitan dengan kehidupan sehari-hari. Penelitian ini bertujuan untuk mengetahui unsur semantik, sintaksis, stilistik dan retoris pada pesan suara Grup tersebut. Teori yang digunakan adalah teori wacana Teun A. Van Dijk. Struktur wacana yang digunakan, yaitu struktur makro, superstruktur dan mikro. Penulis membatasi hanya pada struktur mikro. Elemen semantik dari pesan suara dalam Grup tersebut yaitu makna yang ditekankan dengan memberikan detil. Pada elemen sintaksis bentuk kalimat yang tersusun umumnya bentuk kalimat aktif dengan kata ganti orang pertama (jamak). Pada elemen stilistik pilihan kata yang digunakan umumnya menggunkan "kita". Elemen retoris, ekspresi yang tergambar yaitu optimis dan semangat. Dapat disimpulkan pada tahapan semantik pesan suara pada Grup Line Takeru menyampaikan detil mengenai aqidah dan akhlak. Tahapan sintaksis pesan suara disampaikan dalam bentuk kalimat aktif. Tahapan stilistik pilihan kata pada pesan suara umum digunakan dan dapat dipahami. Tahapan retoris berisi ekspresi narasumber.
\end{abstract}

Kata Kunci: Line; Semantik; Sintaksis; Stilistik; Retoris.

\section{ABSTRACT}

The Line Takeru group packs voicemail containing missionary messages related to everyday life. This research is intended to study the elements, syntax, stylistic and rhetorical in the voices of the Group. The theory used is discourse theory Teun A. Van Dijk. The discourse structure used, namely macro structure, superstructure and micro. The author agrees only on microstructure. The semantic element of voicemail in the Group is the meaning provided by providing details. In the syntactic elements arranged form sentences are generally active sentence forms with first person pronouns (plural). In the stylistic element the choice words used generally use "us". Rhetorical elements, the enthusiasm that is reflected is optimism and 
T. K. Nurazizah, S. Anwar, Bahrudin

enthusiasm. It can be concluded that the semantic stage of the message in the Takeru Line Group is detailed about aqeedah and morality. The syntactic stages of voicemail are delivered in the form of active sentences. Stylistic stages of the choice of words in voice messages are commonly used and can be understood. The rhetorical stage contains the expression of the resource person.

Keywords: Line; Semantics; Syntax; Stilistic; Rhetorical

\section{PENDAHULUAN}

Pada hakikatnya manusia tidak terlepas dari aturan yang menjadi pedoman pada tatanan hidup manusia. Terutama bagi seorang mukmin, Islam mengatur segala aspek kehidupan dengan sedemikian rupa agar hidup yang dijalani terarah di jalan-Nya. Islam pada hakikatnya memberikan rahmat bagi seluruh makhluk. Maka bagi seseorang yang mempelajarinya akan mendapatkan hakikat dari Islam itu sendiri.

Pada hakikatnya manusia tidak terlepas dari aturan yang menjadi pedoman pada tatanan hidup manusia. Terutama bagi seorang mukmin, Islam mengatur segala aspek kehidupan dengan sedemikian rupa agar hidup yang dijalani terarah di jalan-Nya. Islam pada hakikatnya memberikan rahmat bagi seluruh makhluk. Maka bagi seseorang yang mempelajarinya akan mendapatkan hakikat dari Islam itu sendiri.

Islam merupakan agama yang mudah dan tidak memaksa. Seseorang dapat mempelajarainya apabila dirinya sungguh-sungguh sebagai suatu amal kebaikan sebagai seorang Muslim. Sebaliknya, seseorang dapat mempelajarinya hanya untuk memahami hakikatnya saja tanpa mengamalkan segala perintah yang ada di dalamnya.

Bagi seseorang yang ingin mengamalkannya, tentu memiliki keingin dan upaya untuk menyampaikan kembali kepada orang-orang di sekitarnya. Dengan jalan dakwah, seseorang dapat menyampaikan dan mengajak kebaikan kepada individu atau kelompok lain. Hal tersebut tentu harus di lakukan dengan cara yang baik serta tidak memaksa. Sehingga Islam bisa tersampaikan sebagai agama yang damai dan tidak memaksa.

Secara etimologis dakwah berasal dari bahasa Arab (da'a, yad'u, da'watan) yang berarti seruan, panggilan, undangan, atau doa (Tajiri, 2015: 15). Adapun dakwah secara termonologis adalah mengajak seseorang atau satu kelompok menuju jalan yang benar dengan berbagai metode yang dilakukan. Adapun dakwah menurut Ahmad Ghalwusy, menurutnya bahwa "dakwah adalah menyampaikan psan Islam kepada manusia di setiap waktu dan tempat dengan metode-metode dan media-media yang sesuai dengan situasi dan kondisi para penerima pesan dakwah (khalayak dakwah)".

Jadi dapat disimpulkan bahwa dakwah merupakan ajakan atau seruan kepada manusia, baik itu kepada sesama Muslim ataupun non-Muslim dengan 
cara dan media yang sesuai dengan kondisi mad'u. Sehingga dakwah dapat tersampaikan dengan baik sesuai dengan porsi masing-masing mad'u (khalayak dakwah). Dalam aplikasinya, dakwah tidak hanya menyampaikan pesan kebaikan saja. Lebih luasnya dakwah mampu berperan sebagai sarana menjalin silaturahmi melalui komunikasi dua arah yang membuat pesan dakwah itu tersampaikan lebih baik.

Perkembangan pesat di bidang teknologi komunikasi semestinya disikapi secara proaktif. Munculnya era cyber, sudah selayaknya dipandang sebagai peluang sekaligus tantangan guna mewujudkan dakwah Islam yang lebih efektif, efisien, dan mengglobal. Era cyber yang ditandai dengan kian banyaknya masyarakat dunia yang menggunakan internet sebagai media komunikasi, dan sebagai sumber rujukan merupakan tantangan dan peluang bagi para pelaku dakwah (Muhaemin, 2017: 342)

Lebih luasnya lagi, saat ini media telekomunikasi berkembang pesat dari waktu ke waktu. Jaringan internet yang semakin meluas semakin mempermudah seseorang dalam menjalin komunikasi antarsesama. Salah satunya melalui aplikasi-aplikasi obrolan (chatting) dalam smartphone. Seseorang dapat melakukan interaksi dengan banyak orang tanpa batasan ruang dan waktu. Dengan berbagai keunggulan yang ditawarkan dalam setiap aplikasi tersebut, maka akan semakin mempermudah komunikasi terjalin dengan baik.

Salah satu fitur yang dimiliki pada aplikasi chatting saat ini ada fitur pesan suara (voice note). Seseorang dapat melakukan percakapan melalui pesan suara yang direkam dan di sampaikan kepada orang yang kita tuju, lalu tersimpan dalam riwayat obrolan. Kelebihan lainnya, pesan yang disampaikan tidak hanya untuk satu orang saja, namun seseorang bisa menyampaikan pesan tersebut kepada beberapa orang sekaligus, puluhan bahkan sampai ratusan.

Berkaitan dengan dakwah, seorang da'i dapat memanfaatkan aplikasi tersebut sebagai media dakwah. Seorang da'i dapat menyampaikan pesan dakwahnya sekaligus kepada orang banyak. Di samping itu, interaksi antara da'i dan mad'u bisa lebih mudah terjalin karena terhimpun dalam sebuah forum diskusi, sehingga dakwah bisa tersampaikan dengan efektif.

Salah satu grup atau komunitas yang memanfaatkan fitur dari Line tersebut adalah Grup Takeru. Grup Line Takeru ini merupakan forum diskusi dan sharing kagamaan yang beranggotakan 100 orang. Setiap harinya, admin grup ini membagikan materi-materi yang berkaitan dengan akidah, fiqh, maupun ilmuilmu keislaman lainnya dalam bentuk tulisan. Namun dalam grup ini juga membagikan materi keislaman dalam bentuk pesan suara (voice note) yang disampaikan oleh Abu Takeru (A Rizal). Isi pesan suara yang disampaikan berdurasi 1-3 menit dalam satu kali posting. Isi pesan suaranya sendiri terdiri dari pesan-pesan dakwah yang mengarah pada hal-hal yang kita lakukan setiap hari. 
Selain itu penyampaiannya pun memiliki khas tersendiri sehingga membuat peneliti tertarik untuk meneliti pesan dakwah yang disampaikan melalui pesan suara tersebut.

Berdasarkan uraian latar belakang masalah diatas, maka masalah penilitian yang akan dirumuskan sebagai berikut: pertama, bagaimana unsur semantik pada pesan suara dalam grup Line Takeru, kedua, bagaimana unsur sintaksis pada pesan suara dalam grup Line Takeru ketiga, bagaimana unsur stilistik pada pesan suara dalam grup Line Takeru, keempat, bagaimana unsur retoris pada pesan suara dalam grup Line Takeru.

Metode yang digunakan dalam penelitian ini adalah metode analisis wacana. Analisis wacana lebih bersifat kualitatif, karena analisis wacana dapat menggambarkan arti dan tujuan dari apa yang telah diutarakan Abu Takeru dalam pesan suara (voice note) yang di transkip oleh peneliti dalam bentuk teks.

Alasan penggunaan metode analisis wacana ini adalah dari teks tersebut maka akan dapat diketahui elemen-elemen yang ada dari struktur mikro pada penelitian ini.

\section{LANDASAN TEORITIS}

Teori yang dijadikan sebagai landasan adalah teori dakwah komunikasi penyiaran Islam, media sosial, dan teori Teun A. Van Dijk. Secara etimologis dakwah berasal dari bahasa Arab (da'a, yad'u, da'watan) yang berarti seruan, panggilan, undangan, atau doa (Enjang, 2009: 3). Adapun dakwah secara termonologis adalah mengajak seseorang atau satu kelompok menuju jalan yang benar dengan berbagai metode yang dilakukan.

Dalam proses komunikasi, paling tidak, terdapat tiga unsur, yaitu komunikator, media dan komunikan. Para pakar komunikasi juga menjelaskan bahwa komunikasi tidak hanya bersifat informatif, yakni agar orang lain mengerti dan paham, tetapi juga persuasif, yaitu agar orang lain mau menerima ajaran atau informasi yang disampaikan, melakukan kegiatan atau perbuatan, dan lain-lain. Bahkan menurut Hovland, seperti yang dikutip oleh Onong, bahwa berkomunikasi bukan hanya terkait dengan penyampaian informasi, akan tetapi juga bertujuan pembentukan pendapat umum (public opinion) dan sikap publik (public attitude). (Bahrudin, 2010: 828)

Unsur-unsur dakwah ada 5, yaitu: pertama, subjek dakwah (da'i), kata da'i berasal dari bahasa Arab bentuk mudzakkar (laki-laki) yang berarti orang yang mengajak, kalau muannats (perempuan) disebut da'iyah. Dalam kamus bahasa Indonesia da'i diartikan orang yang pekerjaannya berdakwah, pendakwah: melalui kegiatan dakwah para da'i menyebarluaskan ajaran Islam (Enjang AS, 2009: 73-74). Kedua, materi (maudhu), adalah materi, atau pesan-pesan yang berkaitan dengan segala sesuatu yang disampaikan oleh seorang da'i kepada mad'u. Pesan yang disampaikannya berupa ajaran-ajaran Islam yang terdapat 
dalam Alquran dan Alhadis. Ketiga, metode dakwah (uslub), berasal dari bahasa Yunani yaitu methodos, merupakan gabungan dari kata meta yang berarti melalui, mengikuti, sesudah, dan kata hodos berarti jalan, cara. Uslub secara bahasa jalan, seni. Sehingga uslub adalah metode atau cara yang digunakan dalam menyampaikan dakwah. Keempat, objek dakwah (madb'u) adalah seluruh manusia sebagai makhluk Allah yang diberi perintah untuk menjalankan ajaran Islam. Kelima, media dakwah (wasilah al-dakwah), merupakan alat/sarana yang menjadi perantara, penghubung atau saluran yang dapat menyampaikan dan menghubungkan ide atau materi antara da'i dengan mad'u.

Berikut ini adalah definisi dari media sosial yang berasal dari berbagai literatur penelitian: pertama, menurut Mandibergh (2012), media sosial adalah media yang mewadahi kerjasama antara pengguna yang menghasilkan konten (user-generation content). Kedua, menurut Shirky (2018), media sosial dan perangkat lunak sosial merupakan alat untuk meningkatkan kemampuan pengguna untuk berbagi (to share), bekerja sama (to co-operate) diantara pengguna dan melakukan tindakan secara kolektif yang semuanya berada diluar kerangka institusional maupun organisasi. Ketiga, menurut Van Dijk (2013), media sosial adalah platform media yang memfokuskan pada eksistensi pengguna yang memfasilitasi mereka dalam beraktivitas maupun berkolaborasi. Karena itu, media sosial dapat dilihat sebagai medium (fasilitator) online yang menguatkan hubungan antarpengguna sekaligus sebagai suatu ikatan sosial (Nasrullah, 2017: 11).

Berdasarkan wikipedia, Line adalah sebuah aplikasi pengirim pesan instan gratis yang dapat digunakan pada berbagai platform seperti telepon cerdas, tablet, dan komputer. Line difungsikan dengan menggunakan jaringan internet sehingga pengguna Line dapat melakukan aktivitas seperti mengirim pesan teks, mengirim gambar, video, pesan suara, dan lain lain. Line diklaim sebagai aplikasi pengirim pesan instan terlaris di 42 negara.

Berdasarkan wikipedia, Line juga menyediakan fitur group chat yang dapat kita buat sendiri. Dengan kapasitas hingga mencapai 200 orang, kita dapat leluasa mengundang teman-teman kita untuk masuk dalam group chat. Melalui group chat kita dapat mengirim pesan secara serentak kepada teman-teman kita yang terdaftar dalam grup.

Dari begitu banyak model analisis wacana yang dikenalkan dan dikembangkan oleh beberapa ahli, model van Dijk adalah model yang paling banyak dipakai. Hal ini mungkin disebabkan karena van Dijk menformulasikan elemen-elemen wacana, sehingga bisa dipakai secara praktis. Model yang dipakai oleh van Dijk ini sering disebut sebagai "kognisi sosial" (Eriyanto 2001: 221). Menurut van Dijk, penelitian atas wacana tidak cukup hanya didasarkan pada analisis teks semata, karena teks hanya hasil dari suatu praktik produksi yang harus juga diamati. Dalam hal ini harus dapat di lihat bagaimana suatu teks di 
produksi.

Van Dijk membagi struktur teks ke dalam tiga tingkatan. Pertama, struktur makro. Ini merupakan makna global/ umum dari suatu teks yang dapat diamati dengan melihat topik atau tema yang dikedepankan dalam suatu berita. Kedua, superstruktur. Ini merupakan struktur wacana yang berhubungan dengan kerangka atau skema suatu teks, bagaimana bagian-bagian teks tersusun ke dalam berita secara utuh. Ketiga,struktur mikro adalah makna wacana yang dapat diamati dari bagian kecil dari suatu teks yakni kata, kalimat, parafrase dan lainlain.

Struktur mikro terdiri atas beberapa elemen, yaitu: pertama, elemen sintaksis, merupakan salah satu elemen penting yang dimaanfaatkan untuk mengimplikasikan ideologi. Dengan kata lain, melalui struktur sintaksis tertentu, pembaca dapat menangkap maksud yang ada dibalik kalimat-kalimat dalam berita. Melalui struktur sintaksis, wartawan dapat menggambarkan aktor atau peristiwa tertentu secara negatif maupun positif. Kedua, elemen semantik (elemen lokal). Elemen semantik ini sangat erat hubunganya dengan elemen leksikon dan sintaksis sebab penggunaan leksikon dan struktur sintaksis tertentu dalam berita dapat memunculkan makna tertentu. Ketiga, elemen stilitstik. Elemen Stilistik menyangkut pemilihan diksi. Pemilihan diksi telah diketahui dapat mengeskspresikan idiologi maupun persuai, sebagaimana yang terjadi pada "terrorist" dan "freedomfighter". Bagaimana aktor yang sama digambarkan dengan dua diksi yang berbeda berimplikasi pada pemahaman pembaca tenteng aktor tersebut. Keempat, elemen retorik. Elemen retorik menyangkut penggunaan repetisi, alitersi, metafora yang dapat berfungsi sebagai "idiologi control" manakalah sebuah informasi yang kurang baik tentang aktor tertentu dibuat kurang mencolok sementara informasi tentang aktor lain ditekankan. Dengan kata lain, retorik ini digunakan untuk memberi penekanan positif atau negatif terhadap aktor atau peristiwa dalam berita.

\section{HASIL DAN PEMBAHASAN}

Pada tahun 2014 dibuatlah grup Takeru. Dalam waktu satu hari grup line tersebut sudah menerima anggota yang ingin bergabung sebanyak 200 orang. Karena semakin banyaknya antusiasme orang untuk bergabung di grup kajian berbasis online itu, maka Abu Takeru mendapatkan saran untuk membuat official account. Dari official account tersebut, Abu Takeru mem-broadcasting bagi siapa saja yang mau bergabung di grup, maka boleh bergabung dan memiliki kesempatan untung bertanya tiga kali selama seminggu, hal itu di lakukan agar memberi kesempatan kepada yang lain bagi yang ingin bertanya seputar ilmu keislaman.

Karena dirasa ada yang kurang, maka Abu Takeru memanfaatkan fitur voicenote atau pesan suara untuk menyampaikan pesan-pesan singkat, namun 
diupayakan kontennya yang bersifat keseharian dan menyentuh dengan durasi satu sampai empat menit. Adapun awal mula pemberian nama Takeru pada grup tersebut terinspirasi dari nama anak Abu Takeru yaitu Zaid Takeru Nurhadi. Takeru sendiri bermakna teguh, kuat, istiqamah yang jika dalam bahasa Arab tsubut yaitu tetap istiqamah, teguh.

Struktur kepengurusan Grup Line Takeru sebagai berikut. Pertama, ketua: Abu Takeru (Ust. Rizal Fadli Nurhadi), kedua, sekretaris \& bendahara: Syifa (Istri Abu Takeru), ketiga, programmer RM (Rich Message): Fikri \& Yota, keempat, design poster: Firdan.

Peneliti akan menguraikan temuan data dari analisis pesan suara pada grup line Takeru, penulis menggunakan pendekatan kualitatif dengan Metode Analisis Wacana model Teun A. Van Dijk. Penulis membatasi penelitian ini dengan Struktur Mikro yang terdapat pada model analisis tersebut. Struktur atau elemen wacana yang dikemukakan Van Dijk pada Struktur Mikro dapat digambarkan sebagai berikut:

\section{Analisis Pesan Suara pada Grup Line Takeru (Edisi 9 Februari 2018)}

Durasi : 2 menit 21 detik

Tabel 1. Analisis Wacana 1

\begin{tabular}{ll}
\hline Elemen Struktur Mikro & \multicolumn{1}{c}{ Temuan } \\
\hline \multirow{2}{*}{ Semantik } & Latar: dari pesan dakwah edisi 9 Februari 2018 ini \\
& narasumber mengarahkan pendengar pada maksud pesan \\
& yang disampaikan pada paragraf pertama kalimat kedua. \\
& Detail: Pada pesan suara tersebut narasumber \\
& menyampaikan detail pada paragraf kedua. \\
& Maksud: Pada elemen ini narasumber menyuguhkan \\
& parasangka dari kacamata ketidakmampuan manusia. \\
& Pra-anggapan: terdapat pada paragraf terakhir. \\
& Nominalisasi: - \\
& Bentuk kalimat : Aktif Induktif dan Aktif Deduktif \\
& Koherensi: pada paragraf terakhir menunjukkan Sebab- \\
& Akibat pada kalimat \\
& Kata ganti: pada pesan suara tarsebut menggunakan kata \\
Sintaksis & ganti "kita" sebagai orang pertama (jamak), kata ganti "saya" \\
& sebagai orang pertama (tunggal), dan kata ganti "dia" \\
& sebagai orang ketiga (tunggal). \\
& Leksikon: terdapat pada kata "kacamata ketidakmampuan" \\
& Grafis: - \\
Metafora: \\
Ekspresi: optimisme \\
\hline
\end{tabular}

Pada pesan suara yang disampaikan narasumber pada edisi tersebut menjelaskan tentang bagaimana seseorang bersikap optimis dalam beribadah 
kepada Allah. Sikap optimis ini sejalan dengan sifat husnudzan, yaitu berpersangka baik kepada Allah.

Seseorang yang memiliki sifat husnudzan terhadap segala apa yang terjadi kepada dirinya, maka menjadikan apa-apa yang menimpanya di pandang baik oleh dirinya. Artinya seseorang akan selalu merasakan hikmah yang baik dari setiap peristiwa yang menimpanya. Termasuk dalam ber-busnudzan kepada Allah Swt.

Sebagaimana dijelaskan dalam Hadis Riwayat Muslim nomor 4849

"Telah menceritakan kepada kami [Abu Kuraib Muhammad bin Al 'Ala]; telah menceritakan kepada kami [Waki'] dari [Ja'far bin Burqan] dari [Yazid bin Al Asham] dari [Abu Hurairah] dia berkata; Rasulullah shallallahu 'alaihi wasallam bersabda: "Allah 'azza wajalla berfirman: 'Aku sesuai dengan prasangka hamba-Ku terhadap-ku, Aku akan bersamanya jika ia berdoa kepada-Ku".

Dalam hadis tersebut dikatakan bahwasannya Allah sesuai dengan perasangka haba-Nya. Artinya apabila berperasngka baik maka Allah pun akan memberi kebaikan. Begitupun sebaliknya.

Sehingga pesan dakwah yang terkandung dalam pesan suara tersebut adalah seseorang yang senantiasa menanamkan perasangka baik dalam dirinya, maka hal itu pun akan membawa pengaruh baik bagi dirinya. Begitupun ketika berperasangka terhadap Allah, Allah akan memberikan kehidupan yang baik apabila kita juga senantiasa berperasangka baik kepada Allah.

\section{Analisis Pesan Suara pada Grup Line Takeru (Edisi 12 Februari 2018)} Durasi : 1 menit 56 detik

Tabel 2. Analisis Wacana 2

\section{Elemen Struktur Mikro}

Semantik

Sintaksis

\section{Temuan}
Latar: pada pesan suara edisi 12 Februari ini narasumber menyampaikan latar pada paragraph kedua kalimat pertama dan kedua.
Detail: Pada pesan suara tersebut narasumber menyampaikan detail pada paragraf kedua. Maksud: Pada elemen ini terdapat pada paragraf satu kalimat kedua dan ketiga.
Pra-anggapan: terdapat pada paragraf pertama kalimat keempat.
Bentuk kalimat : Pasif Induktif dan Aktif Deduktif Koherensi: pada paragraf terakhir menunjukkan koherensi keadaan pada paragraf terakhir dengan kata bantu "melainkan"
Kata ganti: pada pesan suara tarsebut menggunakan kata ganti "kita" sebagai orang pertama (jamak), kata ganti "aku" sebagai orang pertama (tunggal) 
Stilistik

Retoris
Leksikon: terdapat pada kata "futur"

Grafis: -

Metafora: -

Ekspresi: sedih, penuh harap

Pada pesan suara ini mencakup keseluruhan dari rukun iman tersebut. Sehingga pada pesan suara ini pengertian ini dibahas secara umum, namun yang dititikberatkan adalah mengenai turun naiknya iman seorang hamba kepada Rabbnya.

Seperti yang dijelaskan oleh narasumber pada pesan suara tersebut, iman seorang hamba bisa berada pada posisi yang fluktuatif (naik dan turun). Artinya hal itu menandakan bahwa tingkatan keimanan setiap orang itu berbeda tergantung sejauh mana dirinya mempertahankan posisi keimanannya agar selalu ada di posisi atas.

Turunnya iman seorang hamba dapat disebakan oleh banyak faktor. Dan akibat yang didapat dari turunnya keimanan seorang hamba adalah malas dalam beribadah salah satu contohnya. Ketika seorang hamba merasa malas dalam beribadah secara otomatis kedekatan dengan Rabb-nya menurun.

Allah Swt berfirman dalam Q.S. Al-Anfal: 2.

"Sesungguhnya orang-orang yang beriman ialah mereka yang bila disebut nama Allah gemetarlah hati mereka, dan apabila dibacakan ayat-ayat-Nya bertambahlah iman mereka (karenanya), dan hanya kepada Tuhanlah mereka bertawakkal".

Berdasarkan tasfsirQ, Quraish Shihab menjelaskan maksud dari ayat tersebut adalah sesungguhnya hati orang-orang yang benar-benar beriman selalu dipenuhi rasa takut dan tunduk kepada Allah. Apabila disebut asma Allah hati mereka bergetar dan diliputi rasa takut (haybah). Semakin mereka mendengar ayat-ayat al-Qur'ân dibacakan, semakin kokoh keimanan mereka dan semakin mendalam rasa tunduk serta semakin bertambah pengetahuan mereka pada Allah. Sehingga, pada akhirnya, mereka tidak menyandarkan diri selain kepada Allah yang menciptakan, melindungi, dan memelihara mereka.

Dalam Q.S. At-Taubat: 66.

"Tidak usah kamu minta maaf, karena kamu kafir sesudah beriman. Jika

Kami memaafkan segolongan kamu (lantaran mereka taubat), niscaya

Kami akan mengazab golongan (yang lain) disebabkan mereka adalah orang-orang yang selalu berbuat dosa".

Kedua ayat diatas menjelaskan bahwa turun naiknya iman seorang hamba telah digambarkan oleh Allah dalam ayat-ayat Alquran dari kisah-kisah terdahulu. Dengan demikian, pesan dakwah yang terkandung pada pesan suara ini adalah bagaimana upaya yang harus dilakukan ketika menghandapi kondisi iman yang naik turun (fluktuatif). Sehingga dengan begitu seseorang bisa berusaha menjaga 
imannya agar tetap dalam kondisi yang baik.

Analisis Pesan Suara pada Grup Line Takeru (Edisi 14 Februari 2018) Durasi : 3 menit

Tabel 3. Analisis Wacana 3

\begin{tabular}{ll}
\hline \multicolumn{1}{c}{ Elemen Struktur Mikro } & \multicolumn{1}{c}{ Temuan } \\
\hline \multirow{2}{*}{ Semantik } & Latar: pada pesan suara edisi 14 Februari ini narasumber \\
& menyampaikan latar pada paragraf pertama kalimat satu dan \\
& kedua. \\
& Detail: Pada pesan suara tersebut narasumber \\
& menyampaikan detail pada paragraf kedua. \\
& Maksud: Pada elemen ini terdapat pada paragraf ketiga \\
& kalimat keempat. \\
& Pra-anggapan: terdapat pada paragraf keempat kalimat \\
& pertama. \\
& Nominalisasi: - \\
& Bentuk kalimat : Aktif Induktif dan Aktif Induktif \\
& Koherensi: pada paragraf terakhir menunjukkan koherensi \\
& keadaan pada paragraf terakhir dengan kata bantu "seperti" \\
Sintaksis & Kata ganti: pada pesan suara tarsebut menggunakan kata \\
& ganti "kita" sebagai orang pertama (jamak), kata ganti \\
"mereka" sebagai orang ketiga (jamak) & Leksikon: terdapat pada kata "shahih" \\
& Grafis: - \\
Metafora: - \\
Ekspresi: sedikit rasa ketakutan \\
\hline
\end{tabular}

Pada pesan suara ini, narasumber memberikan penjelasan sebuah hadis yang berkaitan dengan peringatan Allah terhadap orang-orang yang mengutamakan kehidupan dunia dan akhirat. Namun pada pesan suara tersebut, hadis yang disampaikan berupa kutipan tidak langsung sehingga berbentuk ujaran kembali yang disampaikan oleh narasumber.

Hadis yang sama seperti yang dijelaskan oleh narasumber terdapat pada hadis berikut:

"Telah menceritakan kepada kami [Muhammad bin Basysyar] telah menceritakan kepada kami [Muhammad bin Ja'far] telah menceritakan kepada kami [Syu'bah] dari [Umar bin Sulaiman] dia berkata; saya mendengar [Abdurrahman bin Aban bin 'Utsman bin 'Affan] dari [Ayahnya] dia berkata, " [Zaid bin Tsabit] keluar dari sisi Marwan saat siang hari, aku pun berkata, "Tidaklah ia mengutus seseorang kepadanya di waktu seperti ini kecuali untuk menanyakan sesuatu kepadanya. Lalu aku tanyakan kepadanya dan ia pun menjawab, "Sesungguhnya kami menanyakan tentang sesuatu yang pernah kami dengar dari Rasulullah shallallahu 'alaihi wasallam, aku mendengar Rasulullah shallallahu 'alaihi 
wasallam bersabda: "Barangsiapa menjadikan dunia sebagai ambisinya, maka Allah akan mencerai-beraikan urusannya, dan Allah akan menjadikannya miskin. Tidaklah ia akan mendapatkan dunia kecuali apa yang telah di tetapkan baginya. Dan barangsiapa menjadikan akhirat sebagai niatannya, maka Allah akan menyatakan urusannya dan membuatnya kaya hati, serta ia akan di beri dunia sekalipun dunia memaksanya".

Maka pesan dakwah yang disampaikan pada pesan suara tersebut adalah mengingatkan kita agar tidak terlalu nyaman dengan kehidupan dunia sehingga kita lupa tujuan hidup kita di dunia adalah sebagai bekal untuk kehidupan di akhirat kelak.

\section{Analisis Pesan Suara pada Grup Line Takeru (Edisi 18 Februari 2018)}

Durasi : 1 menit

Tabel 4. Analisis Wacana 4

\begin{tabular}{|c|c|}
\hline Elemen Struktur Mikro & Temuan \\
\hline Semantik & $\begin{array}{l}\text { Latar: pada pesan suara edisi } 18 \text { Februari } 2018 \text { ini narasumber } \\
\text { menyampaikan latar pada paragraf pertama kalimat pertama. } \\
\text { Detail: Pada pesan suara tersebut narasumber menyampaikan } \\
\text { detail pada kalimat kedua sampai kalimat kedelapan. } \\
\text { Maksud: Pada elemen ini terdapat pada kalimat ketujuh dan } \\
\text { kedelapan. } \\
\text { Pra-anggapan: terdapat pada kalimat pertama. } \\
\text { Nominalisasi: - }\end{array}$ \\
\hline Sintaksis & $\begin{array}{l}\text { Bentuk kalimat : Aktif Deduktif } \\
\text { Koherensi: Terdapat pada kalimat kedua } \\
\text { Kata ganti: pada pesan suara tarsebut menggunakan kata ganti } \\
\text { "kita" sebagai orang pertama (jamak), kata ganti "aku" sebagai } \\
\text { orang pertama (tunggal), kata ganti "dia" sebagai orang ketiga } \\
\text { (tunggal) }\end{array}$ \\
\hline Stilistik & Leksikon: terdapat pada kata "maksiat" \\
\hline Retoris & $\begin{array}{l}\text { Grafis: - } \\
\text { Metafora: - } \\
\text { Ekspresi: bersyukur }\end{array}$ \\
\hline \multicolumn{2}{|c|}{$\begin{array}{l}\text { Pada pesan suara yang disampaikan, narasumber menjelaskan } \\
\text { bahwasannya seseorang yang memulai atau mengawali harinya dengan } \\
\text { kemaksiatan, maka keberkahan hidupnya akan dicabut oleh Allah. Terdapat pada } \\
\text { Q.S. Al-A'raf: } 96 \text {. } \\
\text { "Jikalau sekiranya penduduk negeri-negeri beriman dan bertakwa, pastilah } \\
\text { Kami akan melimpahkan kepada mereka berkah dari langit dan bumi, } \\
\text { tetapi mereka mendustakan (ayat-ayat Kami) itu, maka Kami siksa mereka }\end{array}$} \\
\hline
\end{tabular}

Tabligh: Jurnal Komunikasi dan Penyiaran Islam Vol. 3 No. 3 (2018) 275-291 
disebabkan perbuatannya".

Pada ayat tersebut, menjelaskan lawan kata dari pernyataan tentang Allah mecabut keberkahan orang yang bermaksiat. Kebalikan dari hal tersebut, ayat ini memberi penjelasan bahwasannya Allah akan memberikan keberkahan kepada mereka yang beriman dan bertaqwa kepada Allah swt.

Maka pada pesan suara ini menekankan bahwa narasumber harus bisa menjaga agar senantiasa mengawali dengan kegiatan positif. Dengan demkian, Allah akan melimpahkan keberkahan dalam hidup. Namun sebaliknya, jika mengawali hari dengan kemaksiatan, maka sebaliknya pula Allah akan mengikis keberkahan dalam hidup.

\section{Analisis Pesan Suara pada Grup Line Takeru (Edisi 23 Februari 2018)}

Durasi : 59 detik

Tabel 5. Analisis Wacana 5

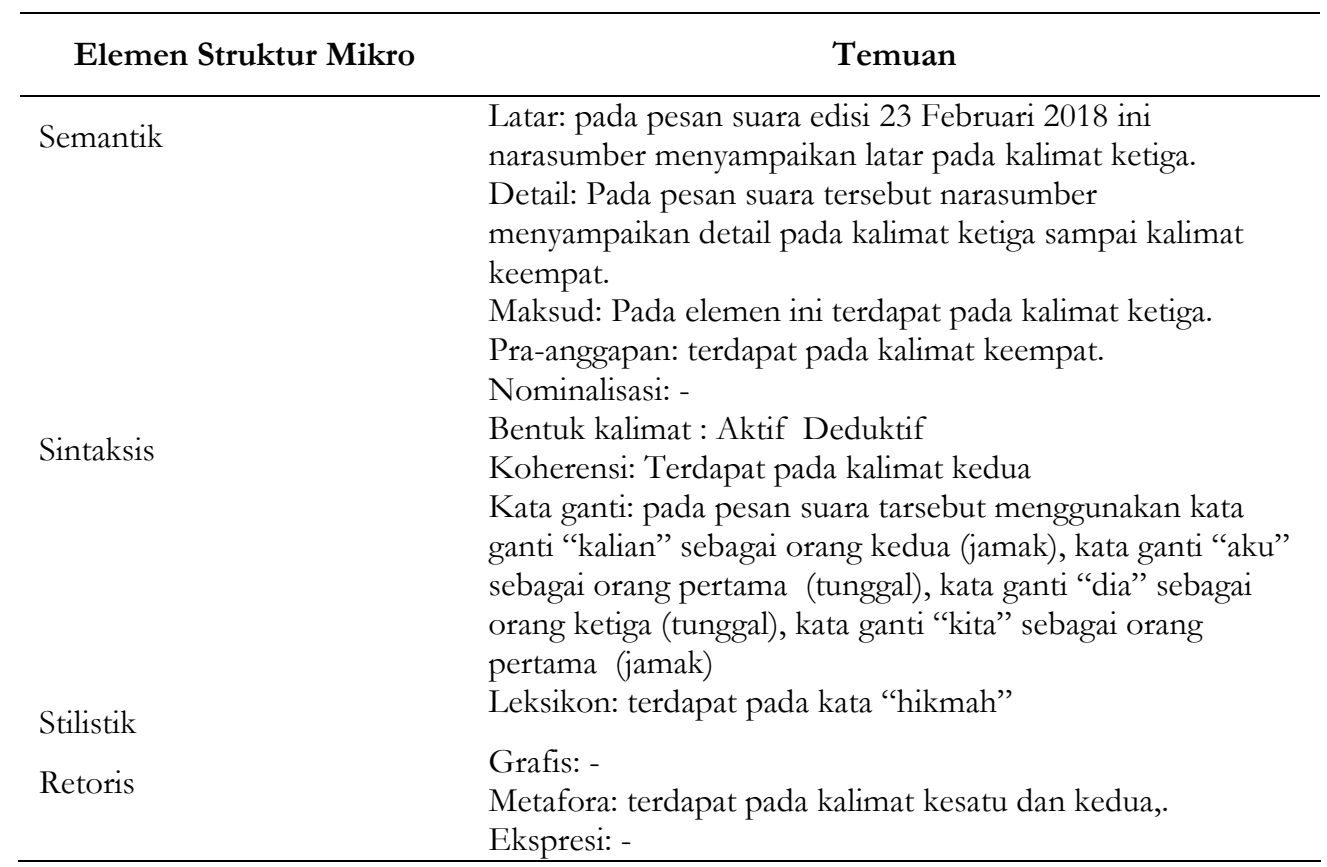

Pada pesan suara ini narasumber menyampaikan hadis dalam bentuk ujaran kembali yang intinya menceritakan tentang kekhwatiran nabi terhadap sahabat-sahabatnya jika tidak melakukan dosa, maka mereka akan menjadi sombong (ujub).

Diantara hikmah yang didapatkan ketika seseorang melakukan perbuatan dosa adalah ketika dirinya merasa sadar bahwa apa yang dilakukannya adalah sesuatu yang haram. sehingga dirinya menebus kesalahannya dengan taubat. Dan taubat itulah yang menjadi hikmah dari perbuatan dosa yang telah dilakukan. 
Allah berfirman dalam Q.S Al-Baqarah: 30.

"Ingatlah ketika Tuhanmu berfirman kepada para Malaikat: "Sesungguhnya Aku hendak menjadikan seorang khalifah di muka bumi". Mereka berkata: "Mengapa Engkau hendak menjadikan (khalifah) di bumi itu orang yang akan membuat kerusakan padanya dan menumpahkan darah, padahal kami senantiasa bertasbih dengan memuji Engkau dan mensucikan Engkau?" Tuhan berfirman: "Sesungguhnya Aku mengetahui apa yang tidak kamu ketahui".

Dengan demikian pesan dakwah yang disampaikan oleh narasumber adalah memberi motivasi kepada pendengar yang merasa dirinya penuh dosa agar senantiasa bertaubat kepada Allah. Dari tumbuhnya kesadaran setelah melakukan perbuatan dosa, maka hal tersebut akan menjadikan dirinya menyesali dan semakin mendekat kepada Allah. Sehingga ada rasa sesal namun termotivasi untuk tidak mengulangi kesalahan yang sama.

\section{Analisis Pesan Suara pada Grup Line Takeru (Edisi 26 Februari 2018)}

Durasi :2 menit 42 detik

Tabel 6. Analisis Wacana 6

\begin{tabular}{ll}
\hline Elemen Struktur Mikro & \multicolumn{1}{c}{ Temuan } \\
\hline Semantik & Latar: pada pesan suara edisi 26 Februari 2018 ini \\
& narasumber menyampaikan latar pada paragraf kedua \\
& kalimat kedua. \\
& Detail: Pada pesan suara tersebut narasumber \\
& menyampaikan detail pada paragraf kedua. \\
& Maksud: Pada elemen ini terdapat pada paragraf kedua \\
& kalimat ketiga dan keempat. \\
& Pra-anggapan: terdapat pada kalimat keempat. \\
& Nominalisasi: - \\
& Bentuk kalimat : Aktif Induktif, aktif deduktif \\
& Koherensi: Terdapat pada kalimat kedua \\
& Kata ganti: pada pesan suara tarsebut menggunakan kata \\
& ganti "kamu” sebagai orang kedua (tunggal), kata ganti "dia" \\
sebagai orang ketiga (tunggal), & kata ganti “-ku" sebagai kata ganti kepemilikkan, dan kata \\
Sintaksis & ganti "kita" sebagai orang pertama (jamak) \\
& Leksikon: terdapat pada kata "taubat nasuhah" \\
& Grafis: - \\
Metafora: terdapat pada pargraf pertama. \\
Ekspresi: -
\end{tabular}

Pada pesan suara ini narasumber mengisahkan sebuah hadis tentang seorang pembunuh yang telah membunuh sembilan puluh sembilan orang dan ingin bertaubat, namun dirinya sempat putus asa karena pernyataan seseorang 
bahwa dirinya tidak akan diampuni, sehingga akhirnya pembunuh itu membunuh lagi orang tersebut hingga genap jumlah orang yang dibunuhnya menjadi seratus orang.

Hadis utuh yang mengisahkan kisah tersebut dalam kitab Sunan Ibnu Majjah, hadis nomor 2612.

"Telah menceritakan kepada kami [Abu Bakar bin Abu Syaibah], telah menceritakan kepada kami [Yazid bin Harun], telah memberitakan kepada kami [Hammam bin Yahya] dari [Qatadah] dari [Abu Shiddiq An Naji] dari [Abu Sa'id Al Khudri], ia berkata; "Tidakkah ingin aku beritahukan kepada kalian sesuatu yang keluar dari mulut Rasulullah shallallahu 'alaihi wasallam? Aku mendengar dengan kedua telingaku dan hatiku menyimaknya, beliau bersabda: "Sesungguhnya terdapat seseorang yang telah membunuh sembilan puluh sembilan orang, kemudian ia ingin bertaubat, lalu ia bertanya tentang seseorang yang paling alim di muka bumi ini. Kemudian ia ditunjukkan kepada seseorang. Ia pun mendatanginya dan berkata; "Aku telah membunuh sembilan puluh sembilan orang, apakah masih ada taubat untukku? Orang tersebut berkata dengan nada terkejut, "Apa? Telah membunuh sembilan puluh sembilan orang?" Beliau melanjutkan; "Akhimya pembunuh itu mengeluarkan pedangnya dan membunuh orang tersebut. Dengan demikian genaplah seratus orang yang dia bunuh. Dia pun masih berkeinginan taubat dan bertanya tentang orang paling alim di muka bumi. Kemudian ia ditunjukkan kepada seseorang dan ia pun mendatanginya. la bertanya; "Aku telah membunuh seratus orang, maka apakah masih ada taubat untukku?" Orang alim itu menjawab; "Celakalah kau! Siapakah yang dapat menghalangimu untuk bertaubat? Keluarlah dari perkampungan yang buruk yang engkau telah diami dan pindahlah ke perkampungan yang baik, yaitu di kampung ini dan ini. Beribadahlah kepada Tuhanmu di sana.

Lalu pembunuh itu pun keluar menuju perkampungan yang baik tersebut, namun ajal menjeputnya di tengah perjalanan. Kemudian malaikat rahmat dan malaikat azab saling berselisih. Iblis berkata; "Akulah yang lebih berhak terhadap orang ini, ia tidak pernah menentang perintahku sama sekali. Malaikat rahmat menjawab, "la telah keluar dalam rangka taubat." [Hammam] berkata; telah menceritakan kepadaku [Humaid At Thawil], telah menceritakan kepadaku dari [Bakar bin Abdullah] dari [Abu Rafi'], ia meriwayatkan; "Allah subhanahu wata'ala mengutus para malaikat, mereka berseteru mengenai hal ini lalu mereka kembali. Allah subhanahu wata'ala lalu berfirman, "Lihatlah, mana dintara dua perkampungan itu yang lebih dekat padanya (kampung maksiat atau kampung yang baik)?" lalu golongkanlah ia pada penghuni kampung tersebut." [Qatadah] berkata; telah menceritakan kepada kami [Al Hasan], ia berkata, "Saat ajal 
menjemputnya, ia melompat hingga lebih dekat kepada perkampungan yang baik, dan perkampungan yang buruk lebih jauh, Kemudian ia dianggap sebagai penduduk kampung yang baik." Telah menceritakan kepada kami Abu Al Abbas bin Abdullah bin Isma'il Al Baghdadi, telah menceritakan kepada kami 'Affan, telah menceritakan kepada kami Hammam, ia menyebutkan yang semisalnya".

Hikmah yang dapat diambil dari hadis tersebut adalah janganlah kita berputus asa terhadap rahmat Allah. Sekalipun kita penuh dosa sebanyak apapun yang tidak terhitung jumlahnya, kita harus punya keyakinan bahwa ampunan Allah itu Maha Luas. Hal ini dijelaskan dalam Q.S. Al-Maidah: 74.

"Maka mengapa mereka tidak bertaubat kepada Allah dan memohon ampun kepada-Nya?. Dan Allah Maha Pengampun lagi Maha Penyayang”.

\section{Analisis Pesan Suara pada Grup Line Takeru (Edisi 28 Februari 2018)}

Durasi : 1 menit 57 detik

Tabel 7. Analisis Wacana 7

\section{Elemen Struktur Mikro}

Semantik

Stilistik

Retoris

\section{Temuan}

Latar: pada pesan suara edisi 28 Februari 2018 ini narasumber menyampaikan latar pada paragraf pertama kalimat kedua.

Detail: Pada pesan suara tersebut narasumber menyampaikan detail pada paragraf kedua.

Maksud: Pada elemen ini terdapat pada paragraf pertama kalimat keenam.

Pra-anggapan: terdapat pada paragraf kedua kalimat keenam.

Nominalisasi: -

Sintaksis Bentuk kalimat: Aktif deduktif, aktif induktif

Koherensi: Terdapat pada paragraf pertama kalimat kelima.

Kata ganti: pada pesan suara tarsebut menggunakan kata

ganti "dia" sebagai orang ketiga (tunggal),

dan kata ganti "kita" sebagai orang pertama (jamak)

Leksikon: terdapat pada kata "seneng"

Grafis: -

Metafora: terdapat pada pargraf pertama.

Ekspresi: -

Pesan dakwah yang disampaikan pada pesan suara ini adalah agar senantiasa berbuat baik dengan perasaan hati yang ikhlas, takut dan rasa harap kepada Allah. Sehingga dengan begitu Allah tidak akan menyia-nyiakan kebaikan kita dengan mendekat pada-Nya. Allah Swt berfirman dalam Q.S. Al-Baqarah: 112.

"(Tidak demikian) bahkan barangsiapa yang menyerahkan diri kepada 
Allah, sedang ia berbuat kebajikan, maka baginya pahala pada sisi Tuhannya dan tidak ada kekhawatiran terhadap mereka dan tidak (pula) mereka bersedih hati".

Pada ayat tesebut Allah memerintah setiap orang untuk senantiasa berbuat baik. Karena kebaikan yang di lakukan akan berbalik pula kepada dirinya. Selain itu, dalam melakukukan kebaikan itu manusia harus memiliki sifat tawadhu.

\section{PENUTUP}

Berdasarkan hasil analisis tehadap data yang dikumpulkan, dapat ditarik kesimpulan sebagai berikut: Pertama, dari unsur semantik ini meliputi latar yang berisi latar belakang dari pembahasan tema pada pesan suara tersebut, detil yang berisi penjelasan secara rinci dari tema yang disampaikan, maksud yang berisi penjelasan lain dari suatu kalimat, pra-anggapan yang memberikan penguatan penguatan terhadap suatu kalimat yang tidak dapat diganggu gugat, dan nominalisasi yang menjelaskan jumlah tertentu. Keseluruhan pesan suara yang dianalisis hampir semuanya memenuhi unsur tersebut, kecuali pada unsur nominalisasi, tidak ditemukan adanya elemen tersebut karena kebanyakan dari isi pesan suara yang disampaikan tidak ada yang berkaitan dengan pembahasan yang mengarah pada nominalisasi yang menunjukkan jumlah tertentu. Namun untuk unsur yang lainnya hampir keseluruhannya memenuhi.

Kedua, dari unsur sintaksis terdapat beberapa unsur sintaksis yang sering nampak. Unsur sintaksis ini meliputi bentuk kalimat, koherensi yang berisi keterkaitan antara kalimat yang berbeda, dan kata ganti yang digunakan pada subjek dalam pesan suara tersebut. Dari ketiga elemen tersebut, bentuk kalimat yang digunakan kebanyakan menggunakan kalimat aktif. Sedangkan kata ganti yang digunakan lebih sering menggunakan kata ganti "kita" sebagai orang pertama (jamak), dan terdapat beberapa koherensi yang menghubungkan antara kalimat satu dengan lainnya yang berbeda makna.

Ketiga, dari unsur stilistik terdapat beberapa unsur stilistik yang sering nampak. Unsur ini meliputi elemen leksikon, yaitu pilihan kata yang digunakan. Hampir seluruh pesan suara yang dianalisis pada sebelumnya memenuhi unsur sintaksis ini, dimana terdapat beberapa pilihan kata yang digunakan dari beberapa pilihan kata yang bermakna sama.

Keempat, Dari unsur retoris beberapa pesan suara yang telah dipaparkan pada bab sebelumnya, terdapat beberapa unsur retoris yang sering nampak. Unsur ini meliputi grafis yaitu penggambaran dalam bentuk tulisan atau gambar, metafora pemilihan kata yang bukan dalam arti sebenarnya, dan ekspresi yang berupa pengungkapan perasaan yang digambarkan narasumber. Dari ketiga elemen tersebut yang sering muncul adalah elemen ekspresi, karena hal tersebut tergambar dari nada bicara yang disampaikan pada setiap pesan suara. Sedangkan unsur grafis tidak ditemukan karena tidak ada penggambaran bentuk tulisan yang 
dibedakan atau gambar yang menyertai. Adapun untuk elemen metafora sedikit ditemukan karena kebanyakan dari kalimat yang disampaikan menggunakan pilihan kata dalam makna yang sebenarnya, serta tidak terdapat istilah perumpamaan, atau ayat Alquran yang disampaikan secara langsung sesuai teks yang sebenarnya.

Kepada para akademisi yang berminat melakukan penelitian sejenis, agar lebih menekankan penelitian pada aspek pra-anggapan yang tidak hanya memberikan penguat pada kalimat sebelumnya, tetapi juga menjadikan kalimat yang tidak dapat diganggu gugat lagi kebenarannya.

Grup Line Dakwah menyajikan puluhan posting-an pesan-pesan dakwah yang disajikan dalam bentuk tulisan maupun pesan suara. Namun, seperti yang disampaikan oleh Abu Takeru, selaku founder, pesan dakwah yang disampaikan melalui sebuah grup dakwah mengundang banyak peminat pengguna media sosial, namun kurang efektif apabila grup dakwah yang dibuat berisi pesan-pesan atau chat dari anggota yang menumpuk sehingga menimbun inti pesan dakwah yang telah disampaikan pada grup tersebut. Maka akan lebih baik jika para pegiat dakwah yang berdakwah melalui media sosial khususnya melalui grup chat, agar meminimalisir pesan yang kurang penting dari setiap anggotanya, sehingga dakwah yang disampaikan bisa lebih efektif.

\section{DAFTAR PUSTAKA}

Aziz, M. A. (2009). Ilmu Dakwah. Jakarta: Kencana.

Bahrudin. (2010). Prinsip-Prinsip Komunikasi dalam AL-Qur'an dalam Ilmu Dakwah: Academic Journal for Homiletic Studies, 4(15), 827-838.

A.S, Enjang \& Aliyudin. (2009). Dasar-dasar Ilmu Dakwah. Bandung: Widya Padjajaran.

Eriyanto. (2001). Analisis W acana. Yogyakarta: LKIS.

Muhaemin, E. (2017). Dakwah Digital Akademisi Dakwah dalam Ilmu Dakwah: Academic Journal for Homiletic Studies, 11(2), 341-356.

Nasrullah, R. (2017). Media Sosial. Bandung: Simbiosa Rekatama Media.

Tajiri, H. (2015). Etika dan Estetika Dakwah Perspektif Teologis, Filosofis, dan Praktis). Bandung: Simbiosa Rekatama Media.

Tafsiq (2015). Surat Al-nfal Ayat 2, diakses 15 Juni 2018, dari https://tafsirq.com/8-al-anfal/ayat-2\#tafsir-quraish-shihab

Wikipedia (2017). Line, diakses 28 April 2019, dari https://id.wikipedia.org/wiki/LINE 